\title{
Parotid Gland Acinic Cell Carcinoma
}

National Cancer Institute

\section{Source}

National Cancer Institute. Parotid Gland Acinic Cell Carcinoma. NCI Thesaurus. Code C5933.

An adenocarcinoma with serous acinar cell differentiation that arises from the parotid gland. Patients usually present with a slow growing mass in the parotid area. 